\title{
Sustainable Production and the Performance of South African Entrepreneurs in a Global Supply Chain. The Case of South African Table Grape Producers
}

\author{
Peter J. Ras ${ }^{1 *}$ and Walter J. V. Vermeulen ${ }^{2}$ \\ ${ }^{1}$ Department of Management and Entrepreneurship, Tshwane University of Technology, South Africa \\ ${ }^{2}$ Copernicus Institute for Sustainable Development and Innovation, Utrecht University, The Netherlands
}

\begin{abstract}
Global trade is strongly growing and becoming connected to the issue of sustainable development in business practices. In recent years this has resulted in businesses on the demand side formulating sets of requirements for suppliers on their performance on corporate social responsibility and sustainable production. In doing this, value systems of the industrialized world are forwarded towards developing countries. It is seen as a way to complement poor sustainability policies on practices in these countries. This relatively new phenomenon of promoting sustainable development through market interactions is quite remarkable. Why would economic actors take up such public interests (abating environmental degradation and social injustice)? From the perspective of developing countries on the supply side of global value chains, being able to commit to such business-to-business standards requires developing world producers to possess certain qualities and capacities. This article reflects on this issue, identifying essential capacities, drawn from literature on (sustainable) entrepreneurship. It develops a model explaining business performance with characteristics of entrepreneurship. The model is tested in practice using data on exporters of table grapes in South Africa. Copyright (C) 2009 John Wiley \& Sons, Ltd and ERP Environment.
\end{abstract}

Received 19 November 2008; revised 30 April 2009; accepted 7 May 2009

Key words: entrepreneurship; sustainability; economic sustainability; global supply chain

\section{Introduction}

ustaINABLE BUSINESS PRACTICES HAVE BECOME A PREREQUISITE FOR SUPPLIERS (ENTREPRENEURS) WITHIN GLOBAL supply chains (Seuring, 2004, p. I629). Various studies have been done on sustainable global supply chain management, identifying various motives ranging from strategic and pragmatic reasons (Hart, I997; Gereffi et al., 2005) to forms of 'enlightened' entrepreneurship (Runhaar et al., 2006; Vermeulen and Ras,

*Correspondence to: Peter J. Ras, Department of Management and Entrepreneurship, Tshwane University of Technology, South Africa. E-mail: raspj@tut.ac.za 
2006; Muller et al., 2009). Although the debate on sustainable production initially focused on environmental issues in production and product development (Huisingh and Bailey, I982; Tibbs, I991; Socolow, I994), it has developed to include social, ethical and economic aspects impacting business (Elkington, I998; Cramer et al., 2004). Profitability as part of the economic aspect is of extreme importance to entrepreneurship in countries such as South Africa, as whole communities are empowered by income geared through international trade.

The South African government has through its Small Business Act indicated that it wants to create long term employment and to level the playing fields between small and large business. This implies moving away from subsistence farming in especially the rural areas to creating small businesses and to growing them into larger businesses, which are able to make a difference locally by creating jobs and prosperity. In this context globalization implies taking up opportunities offered by international trade, which is an important way of generating income (GDP) and securing international investment. To do this supply chain networks, flows of goods and services, and connecting countries are needed.

Supply chain management connects various actors from both the demand and supply sides. Within such global supply chains socio-ethical and environmental value systems developed in the industrialized world are forwarded towards the developing world and are seen as a way to complement poor sustainability policies on practices in these countries (Hess and Coe, 2006; Bek et al., 2007; Muller et al., 2009).

Previous research on the producer addressing the call for sustainable production has shown that South African entrepreneurs active in global product chains face certain barriers, such as lack of required knowledge and expertise on sustainable production, the costs of switching towards sustainable production and a practice in which these costs and the risks of selling products in the European market are put on the shoulders of African suppliers (Dolan and Humphrey, 2004; Ras et al., 2007). These barriers and uncertainties of global markets illustrate that for producers to succeed requires a risk taking attitude and an openness to innovation to keep their supply chain running as smoothly as possible, and it demands good management of the available resources. Thus, it is essential that producers exhibit entrepreneurial qualities to succeed in making profits.

Acknowledging the differences in the global business to business structure, the question emerges of whether South African business actually possess such indispensable qualities to be able to successfully respond to these market demands. Our key questions are the following.

I. To what extent do South African suppliers possess entrepreneurial qualities to enable 'successful' response to European market based sustainability requirements?

2. How do these entrepreneurial qualities relate to the producers' environmental and economic performance?

To answer these questions a discussion on entrepreneurship and management will be followed by an overview of supply chain management and corporate social responsibility literature, to draft an exploratory model. This model will be tested with the results obtained from empirical work done in the field. This article uses data collected in a study of the SATGI and forms part of a larger study investigating sustainability within global supply chains.

\section{Entrepreneurship, Trade and Sustainability}

By connecting global supply chain management to entrepreneurial qualities on the supply side of the chain, we put the concept of entrepreneurship in the centre. Co (2006) defines an entrepreneur as 'someone who identifies a need in the market and develops products and services by making decisions about bringing resources together (raw materials, financial and human resources) to satisfy that need. The entrepreneur takes risks in doing this and is rewarded with the profits of the business'. The role of entrepreneurs as the engine of progress has widely been discussed in the literature, by Mill, Schumpeter, Weber and McClelland (Jennings, I994). The result of entrepreneurship is, according to more recent theorists, the 'creation, enhancement, realization, and renewal of value, not just for owners, but for all participants and stakeholders' (Timmons and Spinelli, 2004), thus also stressing community benefits.

Many authors have addressed typical characteristics of entrepreneurs (Cunnigham and Licheron, I99I), in general distinguishing between psychological traits, as less transferable attitudes or talents or virtues (such as high 
self-esteem, risk taking attitudes), versus more transferable skills in the field of management and planning of business activities and properly controlling the process of running an enterprise. Various authors, including Bull and Willard (I993), Jennings (I994), Timmons and Spinelli (2004) and Etemad (2004) have mapped out this history of theory development and elaborated many such crucial elements of entrepreneurship. Some of the skills and process related characteristics are more or less inward oriented, aiming at controlling the firm itself, while other outward oriented characteristics secure an entrepreneur's interaction with its surrounding world of physical opportunities, such as markets, costumers and society in which enterprises are imbedded, to which it adds value and prosperity and from which it uses human resources.

For this paper we restrict our literature review to summarizing the most commonly suggested elements in Table I, to serve as a basis for our empirical work in the next sections.

In addition to the general debate about (successful) entrepreneurship in the discipline of business management, scholars in the field of sustainable production and corporate social responsibility have suggested comparable features for 'eco-entrepreneurs', 'socially responsible entrepreneurs' or 'sustainable entrepreneurship' (Cohen and Winn, 2007). In this view, creating vision and direction and satisfying ultimate consumer wishes are explicitly connected to developing innovative solutions for environmental issues and acknowledging the direct impacts of entrepreneurial activities on the distribution of prosperity and the depletion of non-renewable resources and ecosystems (Elkington, I994; Hart, I995; Elkington, I998; Larson, 2000). Various types of 'eco-preneur' and 'environmental leader' have been distinguished (Isaak, 2002; Schaltegger, 2002; Runhaar, Tigchelaar et al., 2006). In

Psychological traits

a. High need for achievement $[1,10,11,16,18]$

b. Autonomy and dominance; desire for independence $[2,10,11]$

c. Internal locus of control $[10,12,18]$

d. Tolerance for ambiguity and uncertainty (risk taking) $[3,10]$

e. High propensity for risk taking $[4,18]$

f. Adaptability and flexibility $[5,11]$

g. High self-esteem, self-confidence, self-assurance $[6,7,10,11]$

h. Creativity, innovativeness $[8,10,11,13,15,16,17]$

i. Opportunity recognition, responsiveness, alertness $[9,10,11,13,15,16,17]$

\begin{tabular}{|c|c|c|}
\hline & Inward oriented & Outward oriented \\
\hline Skills & $\begin{array}{l}\text { j. Management skills such as planning ahead, organizing, } \\
\text { control, experience and leadership }[8,10,11,13,17,19] \\
\text { k. Operational skills such as administrative, finance, marketing, } \\
\text { logistics, human resources }[8,10,11,13,17,19] \\
\text { I. Technical skills }[17,18,20]\end{array}$ & $\begin{array}{l}\text { m. Good human relation skills, such as } \\
\text { communication }[13,10] \\
\text { n. Adjust to sector's value systems [15] }\end{array}$ \\
\hline Process & $\begin{array}{l}\text { o. Create a vision and direction }[13] \\
\text { p. Financing the enterprise }[13] \\
\text { q. Good organizers; gather resources such as finance, labour } \\
{[8,11,13,18]}\end{array}$ & $\begin{array}{l}\text { r. Planning for expansion and growth, } \\
\text { addressing market risks }[8,13] \\
\text { s. Planning for competing in the market } \\
{[8,13]} \\
\text { t. Creating networks; such as business, } \\
\text { social and international networks }[13]\end{array}$ \\
\hline Outcome & $\begin{array}{l}\text { u. Wealth creation }[10,13,14] \\
\text { v. Business growth }[10,11,14]\end{array}$ & $\begin{array}{l}\text { w. Employment, community welfare } \\
{[10,13,14]}\end{array}$ \\
\hline
\end{tabular}

Table 1. Characteristics of entrepreneurship as suggested in international literature

[1] McClelland, 1961; [2] Brush, 1992; [3] Schwartz, 1979; [4] Hisrich and Brush, 1987; [5] Buttner and Moore, 1997; [6] Cuba et al., 1983; [7] Rosa et al., 1994; [8] Drucker, 1985; [9] Kirzner, 1999; [10] Timmons and Spinelli, 2004; [11] Van Aardt et al., 2007; [12] Jennings, 1994; [13] Etemad, 2004; [14] Nieman et al., 2007; [15] Cunnigham and Licheron, 1991; [16] Schumpeter, 1936; [17] Peterson, 1985; [18] Bull and Willard, 1993; [19] Robbins and De Cenzo, 2006; [20] Oakey, 2003. 
this perspective, a good entrepreneur is one who understands that consumers on the European and American market demand environmental and social ethical products for consumption and derives profit from it (Porter, I985; Lussier, 2006; Quayle, 2006). A company cannot permit itself to be publicly criticized because of poor working conditions, environmental scandals or a violation of human rights (Cramer, 2006).

The various characteristics of entrepreneurs are especially relevant in the context of global competition, where business standards concerning sustainability from market actors (e.g. retailers) in Europe are being imposed on producers from developing countries. Producers therefore have to comply with various market based standards in order to enter the European market. Sustainable development as a concept and practice is thus promoted through various mechanisms in the market, sometimes by individual firms, such as Tesco's Nature's Choice, and sometimes by joint sector activities, such as GlobalGAP (Muller et al., 2009; Vermeulen, 2008).

In Table I the connection to sustainability implies that additional skills for addressing environmental and social and ethical issues are required, and in the table's row on outcomes positive community impacts and reducing environmental impacts of production and consumption are addressed as well.

For our study we take the underlying basic assumption in this literature as the point of departure. Despite variations in orientation and details, entrepreneurial theory in general departs from the assumption that possessing the psychological traits, inward and outward oriented skills and process related capacities as identified will lead to more success in achieving socio-economic outcomes in the bottom row of the table. Theorists of ecoentrepreneurship would add the assumption that this will coincide with a positive environmental performance.

Summarizing these basic assumptions, we argue that for the subject of our study we can compress the presented variety of characteristics into six main concepts. Stressing the emphasis on creating new opportunities and innovation, 'innovativeness' is the first concept (connecting to items $\mathrm{d}, \mathrm{e}, \mathrm{h}, \mathrm{l}$ and $\mathrm{r}$ in Table $\mathrm{I}$ ). The outward orientation is summarized in the second concept: 'responsiveness' (representing items f, I and o and responses to demands in the field of sustainability). The inward orientation is expressed in 'adequate management' (items j, k, p and q). The fourth concept would be 'business networking' (covering items $\mathrm{m}, \mathrm{n}$ and $\mathrm{t}$ ). The outward orientation also includes two essential concepts for working in the highly competitive international food market: 'market timing', being essential for competing in the dynamics of harvesting schedules and demand fluctuations on the global market (item s), and 'reducing market risks' by planning for supplying multiple crops to multiple markets (item r).

These main concepts are taken in our study as the most relevant competing variables explaining in theory the level of profitability of suppliers in the global supply chain as shown in Figure I. In all cases positive correlations are expected, both with profitability and with environmental performance, as suggested by sustainable entrepreneurship scholars.

\section{Research Methodology}

To test this model we have taken the South African table grape producers as examples of global supply chain participants in industrialized and developing world supply chains.

The empirical data used in this study consists of questionnaire responses from these table grape producers. The questionnaire consisted of three sections: the first addressing the entrepreneur's attitudes and strategies, the second section covering the modes of production and environmental measures. The third section addressed the social issues such as the social benefits provided by the producers to the employees.

The questions were based on our previous research (Ras et al., 2007) and the literature discussed above. All concepts in Figure I have been translated as far as possible into interval scale variables, using seven point Likerttype scales or answers in the form of percentages that had to be filled in. Other questions produced nominal results (such as $\mathrm{I}=$ yes, $2=$ no) and were transformed into summed indexes.

We developed two profitability variables (past profit and expected future profit) as an ordinal variable ranging in seven steps from 'I made losses' and 'no profit' to 'I made more than I2\% profit'. We have chosen this more qualitative approach because profit is a very sensitive issue amongst producers and exact figures would otherwise not be obtained. 


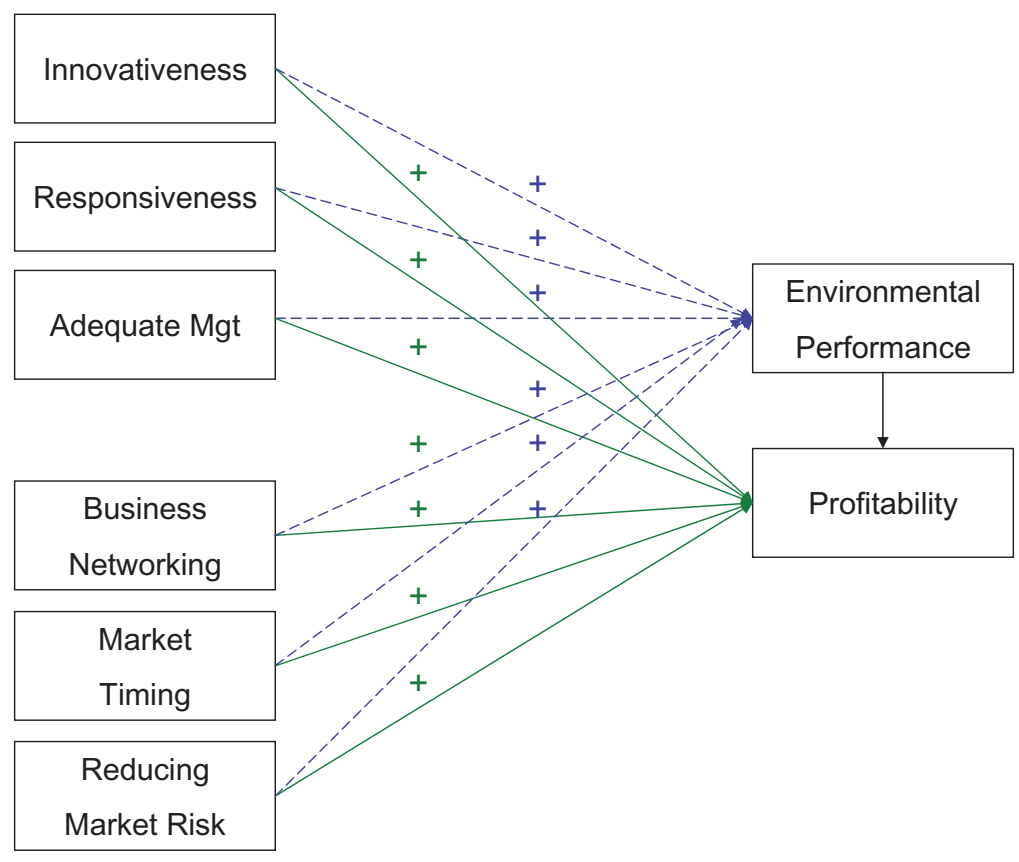

Figure 1. Conceptual model on the relations between main concepts of entrepreneurship and profitability and environmental performance

For the independent variables in Figure I we used the next approach. To determine the first three concepts (innovativeness, responsiveness and adequate management) we formulated I2 statements, covering the various relevant items given in Table I. Answers were collected using a seven point Likert scale. Market risk spreading was addressed with questions about the geographical distribution of the markets accessed by farmers and about the diversification of type of products grown on the farms. These two issues are considered to be the main strategies for risk spreading for producers.

The environmental practices of producers were tested with a set of questions about the self-reported improvements in production practices, based on a comparable study done by Silverman in California (USA) (Silverman et al., 2005), also applying seven point Likert scales. In the interviews we applied a structured questionnaire, including closed questions and using Likert scales, but during these face to face interviews we also verified perceptions and gathered additional information with open ended questions.

\section{Data Collection and Sampling Characteristics}

Empirical findings address a total population of 478 table grape producers, farming in five different geographical areas covering South Africa. The sample frame is presented by data provided by the SATGI.

The research team formed part of a full sector census project undertaken by this industry body that allowed them access to farms. An additional questionnaire was added to producers visited, endorsed and supported by the industry body. We intended to present this additional questionnaire to half of the farmers. For this we applied a convenience sample (Cooper and Schindler, 2006) suitable for working in the South African context. Farmers' participation in the study was affected by different harvesting schedules, lack of physical resources, such as specialized vehicles, lack of time and the need to overcome trust issues with participants. Systematic bias was avoided by a representative response from all geographic regions. In such way $n=242$ producers were visited. Another limitation relates to the fact that only exporting table grape farmers were included in the study. Sustainability practices at locally supplying producers might be different. 
The study target was producers in the table grape industry in South Africa. A pilot study was first conducted during June 2007 , in the smallest region, namely the Olifants River (27 producers only); the weaknesses in the questions were rectified afterwards. The questionnaire was then distributed on a convenience sampling basis in the remaining four regions simultaneously with the census of the table grape industry (Hex River, Orange River, Berg River, Northern Province). All the producers are also the owners of their farms where the table grapes are produced.

\section{Data Analysis}

The questionnaires were captured using SPSS. After initial analysis of the descriptive statistics on the data, using a frequency table, we investigated the model as given in Figure I. For this first we reduced the data on entrepreneurship and applied factor analysis, following the required steps as described in factor analysis literature (Kline, I994). Then we analysed competing explanation with multiple regression analysis (Allison, I999).

In the results section the findings and deductions that were obtained and transformed into meaningful results explaining the profit growth over the past five years and attempting to build a strong $R$ are discussed. A further regression analysis was conducted with the total environmental score as the dependent variable with the objective to build and explain the environmental performance of the producers.

\section{General Table Grape Market Developments}

South Africa is the sixth largest table grape producing country in the world and is engaged in strong competition with Chile, which is the fourth largest producer. Both countries have their produce ready for export to the European and American market at about the same time (United States Department of Agriculture, 2008). Production strongly depends on climatic conditions. Unexpected rain in 2007 in most regions in South Africa resulted in volumes falling by I0-I5\%. Climatic and geographic differences also result in regional variation of the harvest and the connected timing of first market entrance (getting the best prices, especially in December when the market is not yet flooded) between the various South African regions. Price is usually much higher at the beginning, and as more grapes move into the market surplus occurs and price tends to decrease. The 478 producers all export grapes to various overseas markets. The producers make use of a variety of exporters to export their produce on to the market. Many producers supply a certain percentage of their produce to the local market, which does not have the strict regulations of the European or American market. However, the local market is too small to consume the grapes produced and the prices are much lower within the country, and exports are essential to generate income as well as diversifying their production units.

\section{Survey Results: Frequencies}

Good entrepreneurship is essential for producers to survive and make a profit in a free market place, especially in developing countries. Figure 2 presents the table grape producers' profit growth over the past five years.

It shows that $37 \%$ of the producers experienced losses or made no profit at all. The other $63 \%$ all made profits, with I9\% making profits equal to the inflation rate (6\% in the years $2002-2007)$ and $27 \%$ making profits above the inflation rate.

Knowing this, we look at the first group of entrepreneurial characteristics of the producers. These are reflected in the 12 statements in Figure 3.

Looking at these data, we see fairly strong support for statements addressing proper management practices (statements 2, 3, II and I2). Statements connected to corporate social responsibility (7, 8 and 9) are also strongly supported. Remarkable are the results on issues related to innovativeness. At one hand everyone seems to look opportunities (I), but this also reflects selling opportunities of existing produce. This can be seen as the core feature of entrepreneurs. The three statements on innovation however turn out to the most discriminative $(4,5,6$ and Io): one either 'waits and sees' or wants to be on the forefront. 


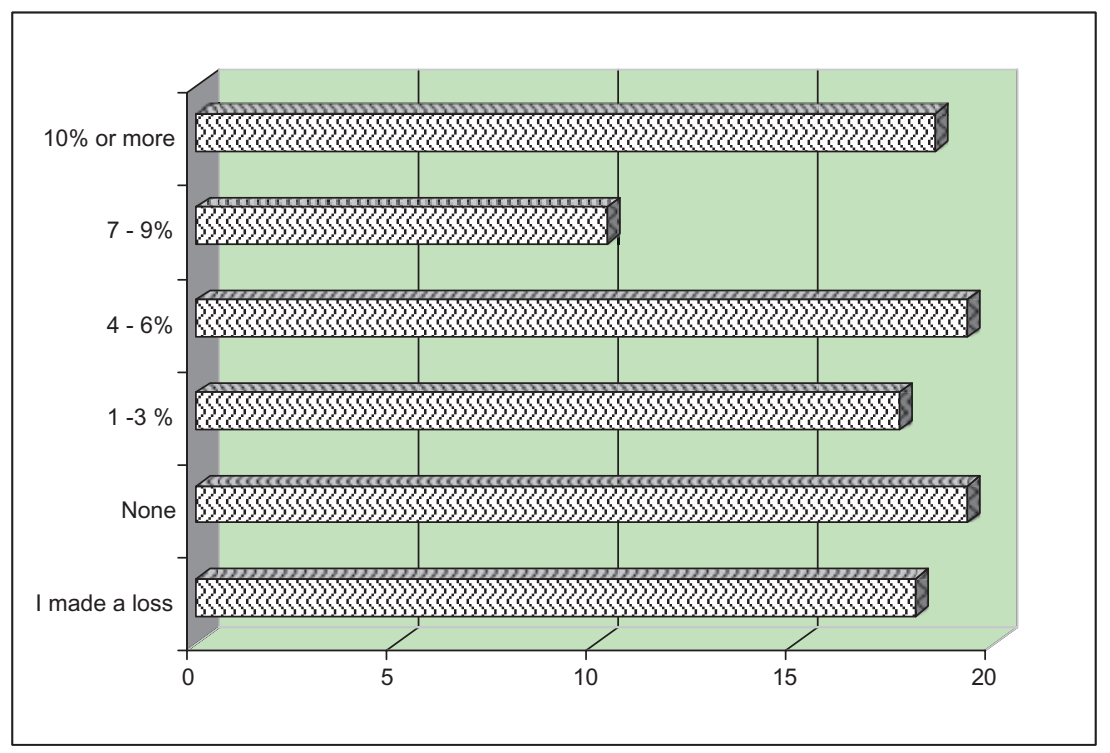

Figure 2. Profit growth of South African table grape producers over the last 5 years $(n=242)$

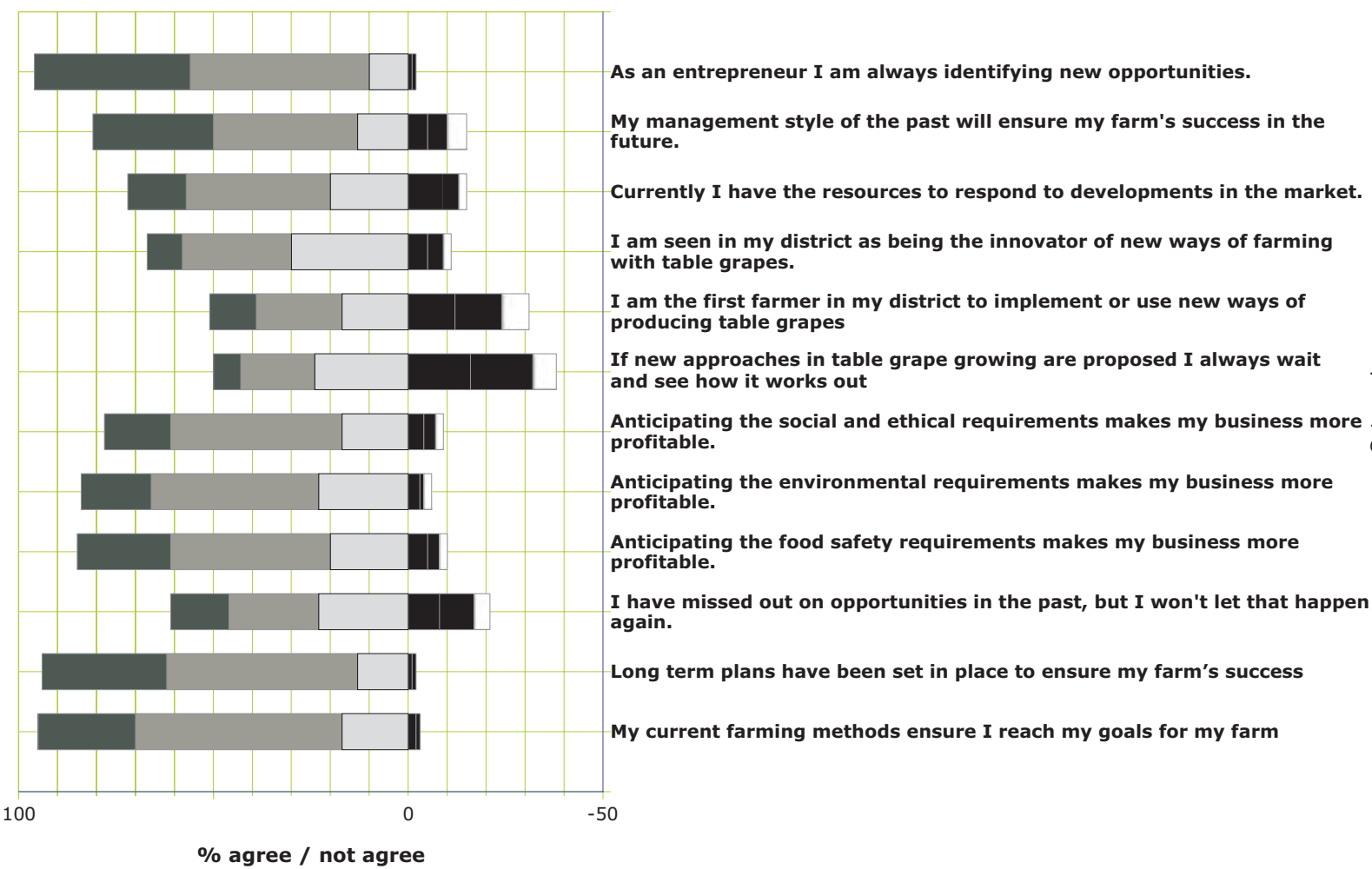

Figure 3. Statements on entrepreneurship by South African table grape producers $(n=242)$ 
Well considered dealing with risks is seen as another virtue of entrepreneurs. In this context this implies strategies of diversification of source of revenue: reducing risks by either diversifying products grown or by geographical markets supplied. The growing of table grapes is a seasonal activity. We determined therefore whether producers depend on just one product for income or have a diverse product spread as an income base. The main source of income for the producers is table grapes $(75 \%)$, as presented in Figure 4 . Other, minor, sources of income are wine grapes and raisins. Some regions are more dependent on income from table grapes, such as the Hex River (85\%), while the Northern region is less dependent (54\%).

The second form of risk reduction is supplying to different markets. Our data in Figure 5 show that currently farmers strongly depend on the European market (75\%), but are considering entering a more diversified mix of

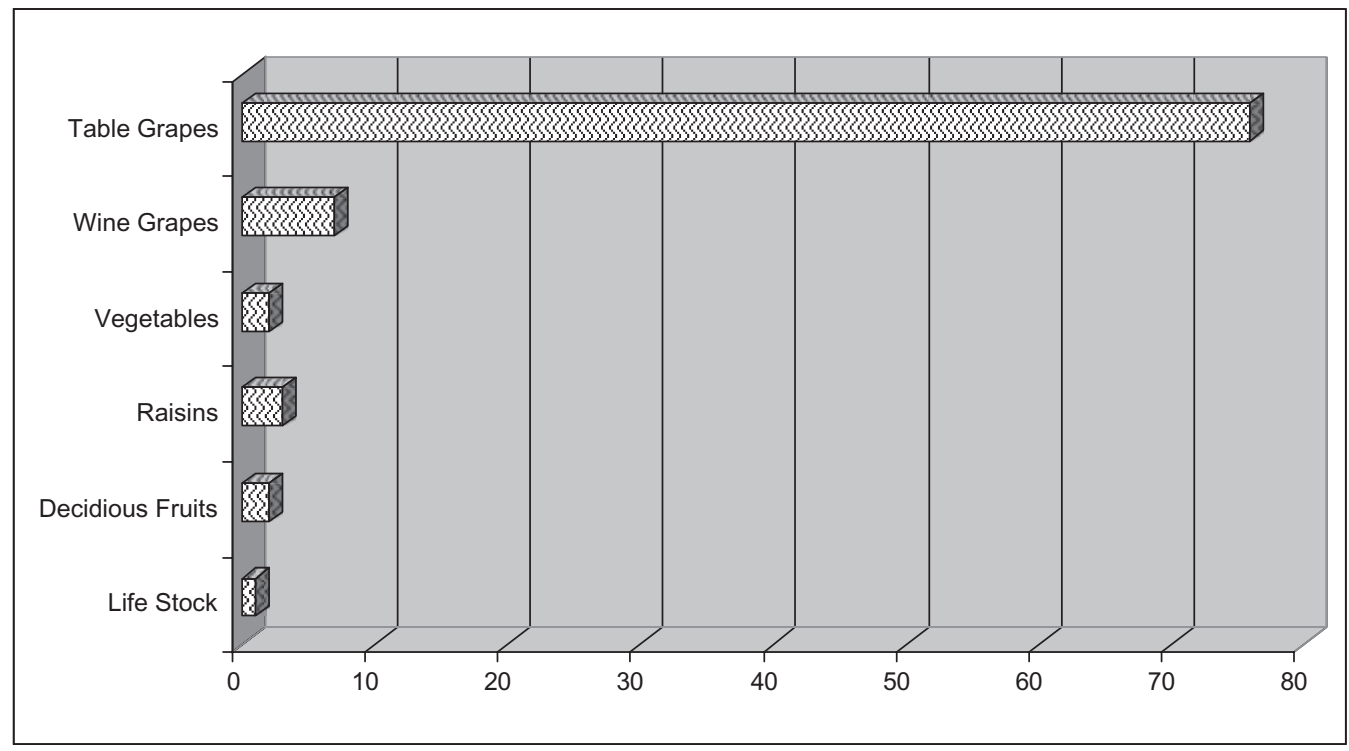

Figure 4. Risk reduction strategies of South African table grape producers: product diversification (average percentage of income from various products, $n=242$ )

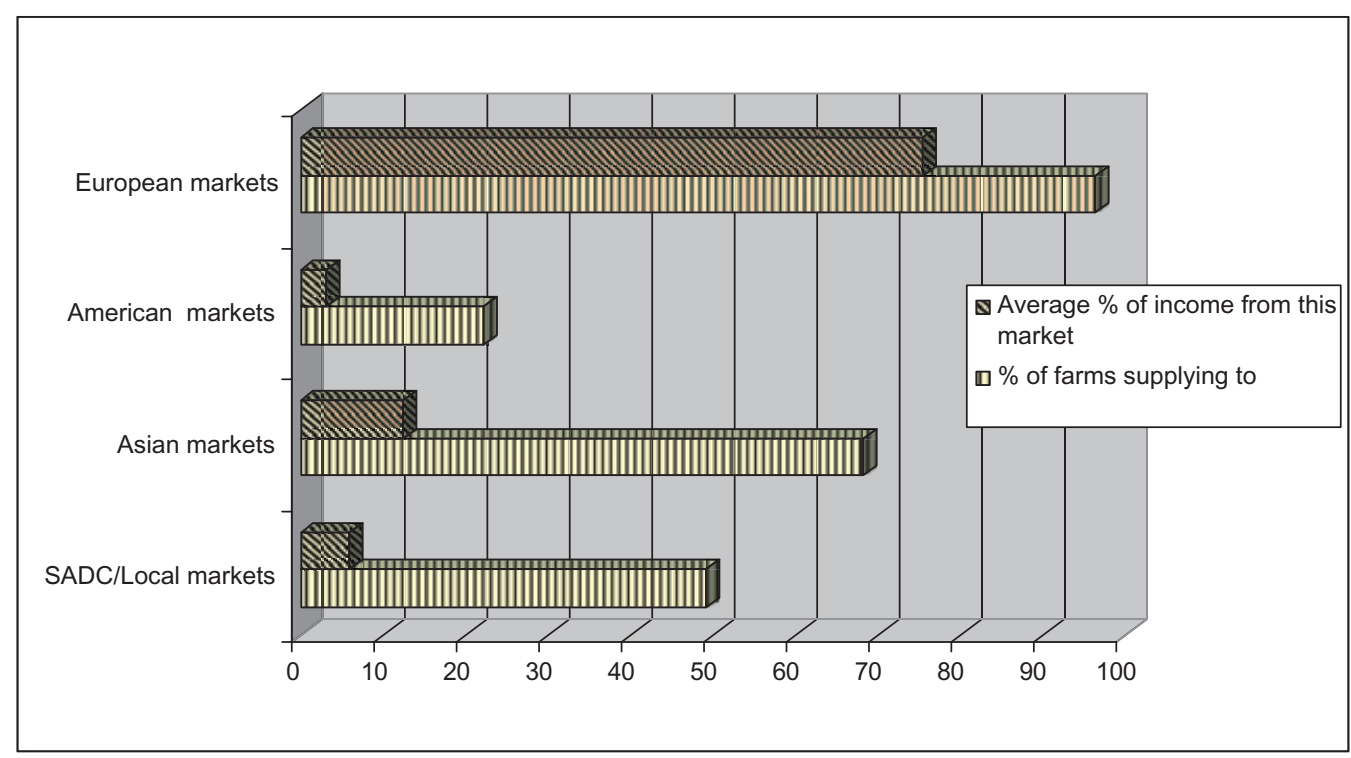

Figure 5. Risk reduction strategies of South African table grape producers: geographical distribution of markets supplied product diversification (average percentage of income from various markets, $n=242$ ) 
markets, with a shift towards the domestic and Asian markets. Yet, the local market is perceived as too small, while exporting to other countries in the southern African region has its own difficulties, such as the political instability of Zimbabwe.

The Asian market is becoming more attractive, as a result of the SATGI initiative to open the market for the South African producers. Exporting grapes has increased especially to China, where some of the clients also started asking for eco-labelled grapes.

Another aspect of entrepreneurship is how one creates a business network and what modes of transactions are used, ensuring stable and profitable seller-buyer relations. This is where supply contracts are relevant. Our data show that in most cases producers do have contracts with exporters or other agents (73\%). Our interviews reveal a typical transaction culture in international trade, as we also referred to above. In these global seller-buyer relations producers are dependent on the willingness of their supply chain partner to pay properly for the produce. A large group of the producers $(42 \%)$ does have to wait more than I 2 weeks for receiving the full payments. In only a few cases $(5 \%)$ the producers are initially paid half of the value of the produce and the rest within six weeks after delivery. A very sensitive issue here is the responsibility for the final sale. In practice very often the responsibility for the produce stays with the producer. What does this mean? The South African producer bears the market risks of the produce until it is sold to the consumer in the European shop and then only is the money transferred to the producer. All the costs encountered to get the product on the overseas market and of the produce not sold (damaged during transport or remainder in the shop) are at the cost of the producer. This is mainly an issue in cases with supply contracts: in these cases $66 \%$ of the contract partners do not pay for damaged or unsold products.

In the context of encouraging corporate social responsibility, European retailers have been introducing various sustainable product certification schemes (see also Muller et al., 2009). We see a very clear response to these business standards by producers in South Africa, as reflected in Figure 6. We saw earlier that the producers supply $75 \%$ of their produce to the EU market. This explains why $95 \%$ of the producers meet the requirements posed in EurepGAP (now renamed GlobalGAP). This is an integrated business-to-business standard on sustainable production, food safety and social issues and the most general programme that has to be followed by any SA producer

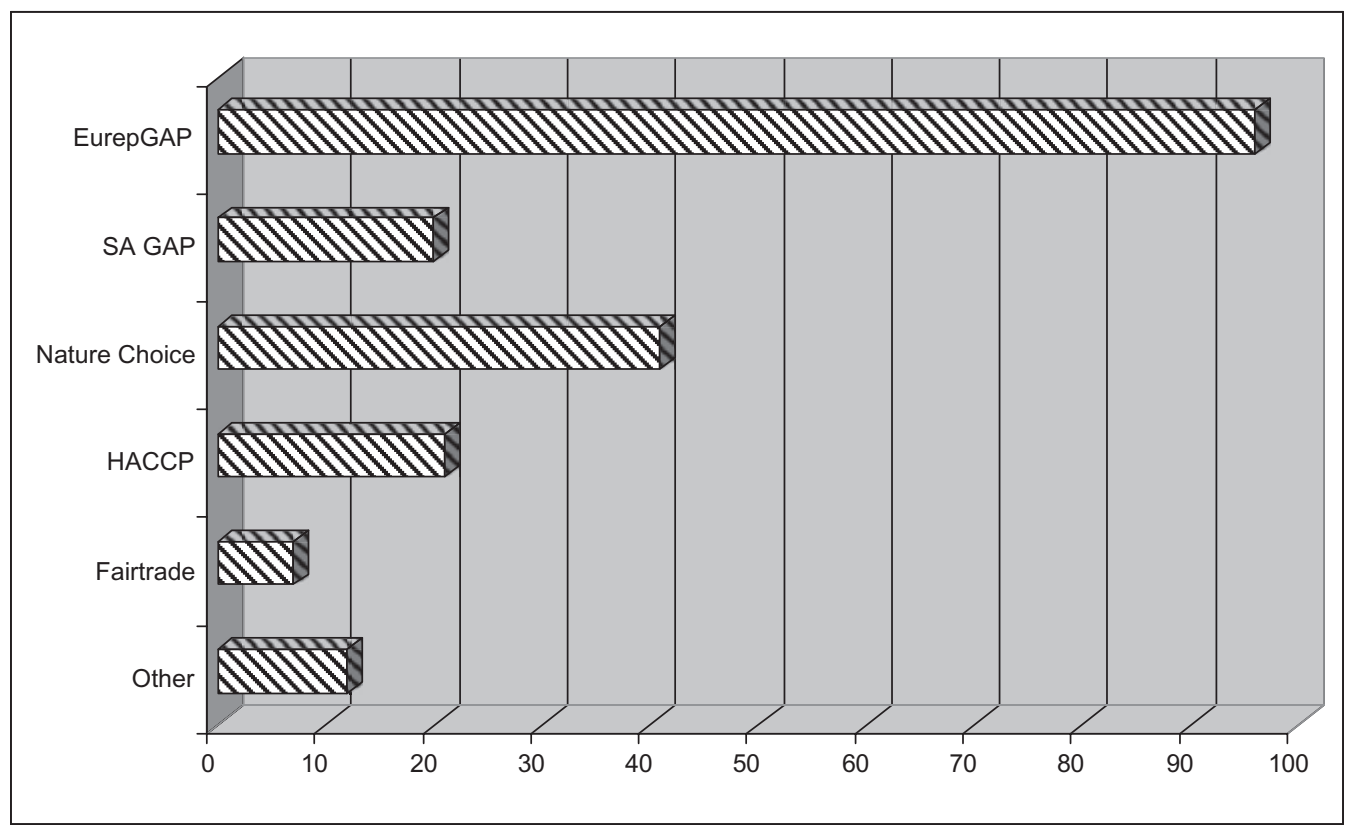

Figure 6. Compliance of South African table grape producers with various business-to-business standard systems (percentage of producers, $n=242$ ) 


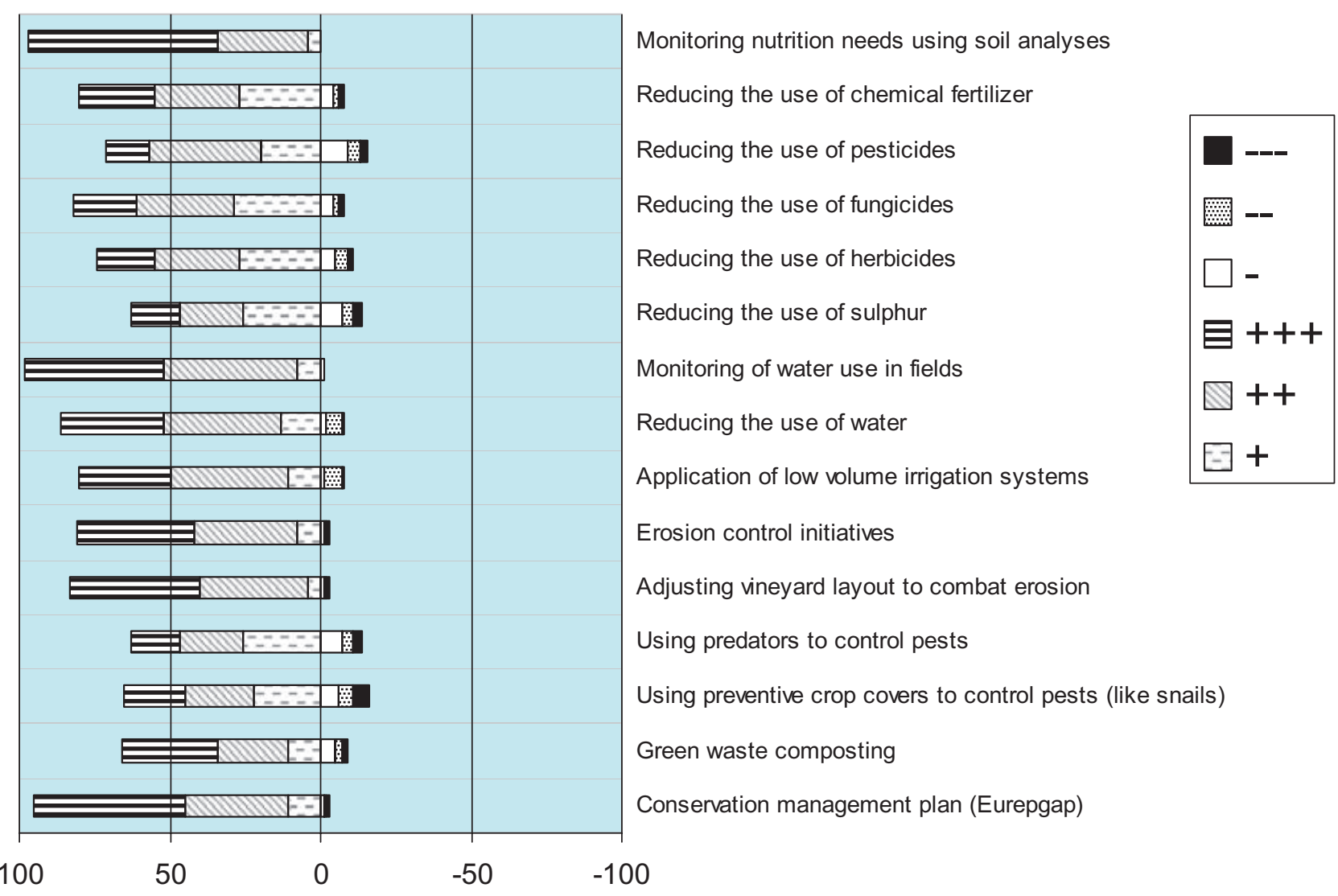

Figure 7. Successfulness in improving environmental performance of South African table grape producers $(n=242)$

that wants to export its fresh produce to the main European retailers. Compliance with the specific single firm requirement scheme of Tesco, called Nature's Choice, is also high (4I\%), while other systems have smaller market shares, with $7 \%$ for Fair Trade.

Compliance with these environmental and other requirements should be reflected in the practices on these farms. As described above, we used a previously applied set of questions relating to the environmental performance of grape growing (Silverman et al., 2005). The data in Figure 7 reflect the successful implementation of environmental practices on the farming units, mainly as a result of the powerful implementation of the GlobalGAP standard. The producers interviewed indicated that the guidelines provided with the GlobalGAP certification contributed to the successful implementation of sound environmental practices. We see the highest success level in monitoring of the nutrition needs using soil analysis and in monitoring of water use. Areas that can still be improved on are reduction of chemical fertilizer and reduction of sulphur. More attention can still be given to using preventive crop covers to control pests such as snails.

\section{Data Analysis: Testing the Conceptual Model}

At this stage we can analyse to what extent the various possible explanations for the business performance of table grape producers on the market, discussed above and for which research data have been given, in practice do correlate with the economic performance, as suggested in the model in Figure I. 
Before testing the conceptual model we applied factor analysis in order to reduce the number of i2 Likert scale variables concerning entrepreneurship (see the appendix for procedural details). Looking at the results of the factor analysis in Table 2, we are able to label the resulting Component I 'innovativeness', because the contributing items stress innovativeness and being first mover. We labelled Component 2 'market responsiveness', because these items stress anticipating various global market demands. The items in Component 3 mainly stress current 'adequate management' practices. These results fit very well within our theoretical expectation.

After the factor analysis, we can make the step to test the relative explanatory power of the various independent variables, as discussed above. We applied multiple regression models with nine independent variables: the three entrepreneurship constructs, two ways of dealing with risks on the market (geographical market diversification and the product diversification), the level of dependency of supply chain partners (through supply contracts) and the level of lost transactions due to products not being sold, and finally the ability of producers to enter the market at the most profitable time. In this way we have tested our conceptual model in Figure I as two multiple regression models, A and B.

The results of the analysis show interesting differences between Model A, explaining environmental performance, and Model B, explaining profitability. First it needs to be stated that we can indeed test the two models separately, as the correlation of these two dependent variables (profitability and environmental performance) is very low (Spearman's rho $=0.098$ ). This in itself is a remarkable result: more attention to environmental management does not lead to better profits, but neither does it lead to reduced profits.

Looking at both regression models as shown in Figure $8,{ }^{\mathrm{I}}$ we see that $15 \%$ of the variation in environmental performance is explained in Model A and $\mathrm{I} 4.5 \%$ of the variance in profitability is explained by Model B.

\begin{tabular}{|c|c|c|c|}
\hline & \multicolumn{3}{|c|}{ Component } \\
\hline & 1 & 2 & 3 \\
\hline $\begin{array}{l}\text { If new approaches in table grape growing are proposed, I always wait and see how it works out } \\
\text { on other farms. }\end{array}$ & -0.779 & & \\
\hline $\begin{array}{l}\text { I am the first farmer in my district to implement or use new ways of producing table grapes } \\
\text { (planting new cultivars etc.). }\end{array}$ & 0.642 & & 0.338 \\
\hline As an entrepreneur I am always identifying new opportunities. & 0.552 & & \\
\hline $\begin{array}{l}\text { Anticipating the environmental requirements posed in the global market will help me to make my } \\
\text { business more economically viable/profitable. }\end{array}$ & & 0.865 & \\
\hline $\begin{array}{l}\text { Anticipating the food safety requirements posed in the global market will help me to make my } \\
\text { business more economically viable/profitable. }\end{array}$ & & 0.813 & \\
\hline $\begin{array}{l}\text { Anticipating the social and ethical requirements posed in the global market will help me to make } \\
\text { my business more economically viable/profitable. }\end{array}$ & & 0.756 & \\
\hline I have missed out on opportunities in the past, but I won't let that happen again. & & 0.491 & \\
\hline $\begin{array}{l}\text { My management style of the past will ensure my farm's success in the future. } \\
\text { My current farming methods ensure I reach my goals for my farm }\end{array}$ & -0.324 & & $\begin{array}{l}0.725 \\
0.619\end{array}$ \\
\hline I am seen in my district as being the innovator of new ways of farming with table grapes. & 0.380 & & 0.592 \\
\hline Currently I have the resources to respond to developments in the market. & & & 0.551 \\
\hline $\begin{array}{l}\text { Long term plans have been set in place to ensure my farm's success (planting strategies, labour } \\
\text { plans etc.) }\end{array}$ & & & 0.382 \\
\hline
\end{tabular}

Table 2. Pattern matrix for factor analysis of 12 variables on entrepreneurship aspects

Extraction method: principal component analysis. Rotation method: Oblimin with Kaiser normalization.

a Rotation converged in 23 iterations.

\footnotetext{
${ }^{\mathrm{I}}$ The explanatory power of a regression model is expressed by the $R^{2}$. This number expresses the total percentage of variance in the dependent variable that is explained by the independent variables in the model. We consider an $R^{2}=0: 30$ (30\% explained by the model) as indicating a good result in social sciences. Yet, Allison (I999) states that its value is at all times of importance, irrespective whether it is high or low. There is no reason to reject a model if the $R^{2}$ is small. In our discussions, we also display the $\beta$ values for each independent variable in the models. The larger the $\beta$ value, the more the level of adoption is explained by this variable. We also show the levels of significance, and set the minimum acceptable level to be $p<0.10$, as also stated by Allison and others (Allison, I999; Pallant, 2007).
} 


\begin{tabular}{|c|c|c|c|c|}
\hline \multirow[t]{2}{*}{ Dependent variable: } & \multirow{2}{*}{\multicolumn{2}{|c|}{$\begin{array}{c}\text { Model A } \\
\begin{array}{c}\text { Environmental } \\
\text { performance }\end{array} \\
R^{2}=0.150\end{array}$}} & \multirow{2}{*}{\multicolumn{2}{|c|}{$\begin{array}{c}\text { Model B } \\
\text { Profitability } \\
\text { past five years } \\
R^{2}=0.145\end{array}$}} \\
\hline & & & & \\
\hline (Constant) & $\beta$ & $\begin{array}{l}\text { Sig. } \\
0.000\end{array}$ & $\beta$ & $\begin{array}{l}\text { Sig. } \\
0.001\end{array}$ \\
\hline Factor 1 Innovativeness & 0.143 & 0.060 & 0.055 & 0.426 \\
\hline Factor 2 Market responsiveness & 0.207 & 0.005 & 0.029 & 0.664 \\
\hline Factor 3 Adequate management & 0.110 & 0.141 & 0.289 & 0.000 \\
\hline Reducing market risks (geographically) & -0.052 & 0.467 & -0.015 & 0.812 \\
\hline Reducing market risks (product diversification) & 0.097 & 0.178 & -0.020 & 0.760 \\
\hline Standards compliance (sum) & -0.044 & 0.566 & 0.096 & 0.162 \\
\hline Networking: supply contract dependency $\%$ & 0.128 & 0.071 & 0.045 & 0.485 \\
\hline Supply contract transaction losses & 0.012 & 0.871 & -0.020 & 0.765 \\
\hline Market timing: first on market & -0.124 & 0.086 & 0.133 & 0.043 \\
\hline
\end{tabular}

Table 3. Multiple regression analysis of possible explanations for 'profitability' and 'environmental performance' $(n=242)$

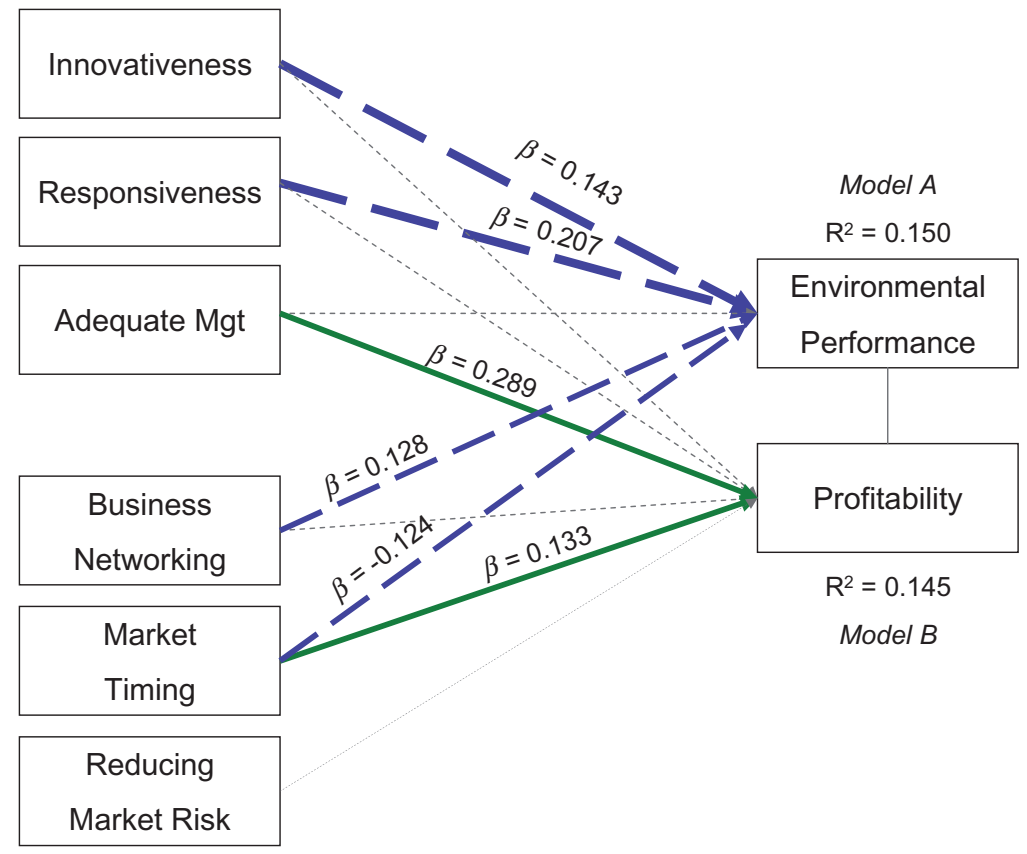

Figure 8. Confirmed and rejected correlations in the conceptual model on the relations between main concepts of entrepreneurship and profitability and environmental performance

Looking at variables with a significance level less than o.Io, we see as the most relevant highlighted explanation for profitability (Model B) the market timing and the third entrepreneurship factor, addressing adequate management practices. Here we see that running your business decently and being able to pick the grains of early delivery is essential for financial business success. Moreover, it shows that all other assumed explanations do not correlate significantly.

In Model A, addressing explanations for success in environmental performance mainly correlates to the other two entrepreneurial constructs: innovativeness and market responsiveness. Market responsiveness relates as we 
saw to responding to CSR related issues in the international markets. This international business-to-business pressure can also been seen in the third accepted explanation: the producers with a higher level of supply contract dependency on supply chain partners (mainly European retailers) prove to be more successful in adopting their environmental practices. Still, market timing is a relevant variable in this as well. We also see that some of the expected explanatory variables do not contribute significantly in either model: the risk spreading strategies, the number of standards participated in and transaction losses due to the supply contract culture.

Both models have a relatively low $R^{2}$, indicating that further research is needed, adding more explanations to the model. Further detailing the accuracy of the data representing the included variables would presumably also increase its explanatory power. We have to stress that we are discussing a new line of research with few comparative examples.

Yet, the analysis shown here does, in its exploratory stage, confirm the assumed rationale behind market governance on sustainable product chains: business-to-business interactions are positively affecting the performance of producers in developing countries, and without negative economic consequences.

\section{Discussion and Conclusions}

To be able to compete on the international market South African producers have to know and understand the conditions and criteria of the market they wish to enter and they need to be able to adapt their enterprise to these market dynamics. We have shown that more than 90\% of the producers meet the GlobalGAP criteria, while fewer farms respond to the standards set by Tesco as a single firm, and a far lower percentage is recorded for Fair Trade. These producers concentrate mainly on supplying to the European market, being a far more lucrative market with better prices than those of local markets. These international supply chain practices are to a large extent structured through supply contracts ( $73 \%$ of the farms have these), where supply chain culture is characterized by long delays for most producers. On top of this the most remarkable feature of this transaction culture is that $66 \%$ farms are not paid for produce that is damaged or non-sold in Europe.

It is important to note that in this context the mainstream European businesses have introduced their businessto-business standards (Nature's Choice; GlobalGAP), with South African producers bearing the costs of compliance and auditing, while no price premiums are given. In this way these standards differ from older types of product standard (for organic and fair trade), which do provide price premiums to producers in developing countries.

Here we see a remarkable phenomenon: the second generation approach (see Vermeulen, 2008) proves to be far more successful (95\% of the farmers complying) than older sustainable product standards (with just $7 \%$ ), while also being well applicable for the producers. However, the economic allocation fairness of these approaches, based on applying market selling power, may very well be questioned.

On the other hand, our data show that there is neither a negative nor a positive correlation between environmental performance and economic performance. In other words: there are no economic arguments for refraining from applying environmental practices on these farms.

Our key questions have been answered in testing the conceptual model. Environmental performance and economic performance prove to have different drivers: the innovativeness and responsiveness to the dynamic market, together with network participation and responding to the market dynamics, are the most relevant explaining variables here. Improving the producer's ability to address the challenges put forward by supply chain partners, can thus best be promoted by strengthening these characteristics of producers.

This contrasts with views emphasizing the more inward oriented management skills of producers for improving environmental practices. Our analysis reveals that these skills are essential for the economic performance of the farms, and for this reason deserve further enhancement, but they are not the most essential in improving environmental responsiveness of producers.

The main conclusions drawn from this study provide a better understanding of the South African table grape producers' position in their dynamic supply chains. Every study has to work within its limitations, as did we. Further analysis of additional explanations aiming at improving the explanatory model is needed, as are comparative studies addressing other products and other trading countries. With this study a step has been made towards more quantitative empirical analysis of recent innovative forms of business-to-business governance for 
sustainable production, which deserves to be challenged in the wider study of supply chains, globalization and sustainable development.

\section{Acknowledgements}

This study is part of Project $06 / 44$, enabled by funding of SANPAD (South African Netherlands Program for Alternatives in Development).

\section{References}

Allison PD. I999. Multiple Regression: a Primer. Pine Forge: Thousand Oaks, CA.

Bek D, McEwan C, et al. 2007. Ethical trading and socioeconomic transformation: critical reflections on the South African wine industry. Environment and Planning A 39(2): 30I-3I9.

Brush CG. I992. Research on woman business owners: past trends, a new perspective and future directions. Entrepreneurship Theory and Practice I6(4): 5-30.

Bull I, Willard GE. I993. Towards a theory of entrepreneurship. Journal of Business Venturing 8(3): I83-I95.

Buttner E, Moore D. I997. Women's organizational exodus to entrepreneurship: self-reported motivations and correlates with success. Journal of Small Business Management 35(I): 34-47.

Co MJ, Groenewald J, Mitchell B, Nayager T, van Zyl J, Visser K. 2006. Entrepreneurship fresh perspectives. $2^{\text {nd }}$ edition, Pearson Education: South Africa, Cape Town.

Cohen B, Winn MI. 2007. Market imperfections, oppertunity and sustainable entrepreneurship. Journal of Business Venturing 22: 29-49.

Cooper DR, Schindler TS. 2006. Business Research Methods. McGraw-Hill: New York.

Cramer J. 2006. Corporate Social Responsibility and Globalisation. An Action Plan for Business. Green Leaf: Sheffield.

Cramer J, Jonker J, et al. 2004. Making sense of corporate social responsibility. Journal of Business Ethics 55(2): 215-222.

Cuba R, Deccenzo D, et al. I983. Management practices of successful female business owners. American Journal of Small Business Management 8(2): 40-45.

Cunnigham JB, Licheron J. I99I. Defining entrepreneurship. Journal of Small Business Management 29(I): I-IO.

Dolan C, Humphrey J. 2004. Changing governance patterns in the trade in fresh vegetables between Africa and the United Kingdom. Environment and Planning A 36(3): 49I-509.

Drucker PF. I985. Innovation and Entrepreneurship. Harper and Row: New York.

Elkington J. I994. Towards the sustainable corporation - win-win-win business strategies for sustainable development. California Management Review 36(2): 90-100.

Elkington J. 1998. Cannibals With Forks: the Triple Bottom Line of 21st Century Business. New Society: Gabriola Island.

Etemad H. 2004. International entrepreneurship as a dynamic adaptive system: towards a grounded theory. Journal of International Entrepreneurship 2: 5-59.

Gereffi G, Humphrey J, et al. 2005. The governance of global value chains. Review of International Political Economy I2(I): 78-I04.

Hart SL. I995. A natural-resource-based view of the firm. The Academy of Management Review 20(4): 986-IOI4.

Hart SL. I997. Beyond greening: strategies for a sustainable world. Harvard Business Review 75(I): 66-79.

Hess M, Coe NM. 2006. Making connections: global production networks, standards, and embeddedness in the mobile-telecommunications industry. Environment and Planning A 38(7): 1205-1227.

Hisrich RD, Brush CG. I987. Women entrepreneurs: a longitudinal study. Frontiers in Entrepreneurs Research. Babson College: Wellesley, MA; I87-I89.

Huisingh D, Bailey V. I982. Making Pollution Prevention Pay: Ecology with Economy as Policy. Pergamon: New York.

Isaak R. 2002. The making of the ecopreneur. Greener Management International (38): 8I-9I.

Jennings DF. I994. Multiple Perspectives of Entrepreneurship: Text, Readings and Cases. South-Western: Cincinnati, OH.

Kirzner IM. I999. Creativity and/or alertness: a reconsideration of Schumpeterian entrepreneur. Review of Austrian Economics Literature II(I/2): 5 -I7.

Kline P. I994. An Easy Guide to Factor Analysis. Routledge: London.

Larson AL. 2000. Sustainable innovation through an entrepreneurship lens. Business Strategy and the Environment 9(5): 304-3I7.

Lussier RN. 2006. Management Fundamentals: Concepts, Applications, Skill Development. $3^{\text {rd }}$ edition Thomas South Western: Boston, MA.

McClelland DC. I96r. The Achieving Society. Van Nostrand: Princeton, NJ.

Muller C, Vermeulen WJV, et al. 2009. Perceptions at demand side and realities at supply side: a case study of the South African Table Grape Export Industry. Sustainable Development in press.

Nieman G, Hough J, et al. 2007. Entrepreneurship A South African Perspective. Van Schaik: Pretoria.

Oakey RP. 2003. Technical entrepreneurship in high technology small firms: some observations on the implications for management. Technovation 23: 679-688.

Pallant J. 2007. SPSS Survival Manual. Open University Press: Maidenhead, Berkshire.

Peterson R. I985. Raising risktakers. Metropolitan Toronto Business Journal 75(7): 30-34.

Porter ME. I985. Competitive Advantage: Creating and Sustaining Superior Performance. Free Press-Collier Macmillan: New York-London.

Quayle M. 2006. Purchasing and Supply Chain Managenment Strategies and Realities. Idea Group: Hershey. 
Ras PJ, Vermeulen WJV, et al. 2007. Greening global product chains: bridging barriers in the north-south cooperation. An exploratory study of possibilities for improvement in the product chains of table grape and wine connecting South Africa and the Netherlands. Progress in Industrial Ecology - an International Journal 4(6): 40I-4I7.

Robbins SP, De Cenzo DA. 2006. Supervision Today. Pearson: Upper Saddle River, NJ.

Rosa P, Hamilton S, et al. I994. The impact of gender on small business management: preliminary findings of a British Study. International Small Business Journal 12(3): 25-32.

Runhaar H, Tigchelaar C, et al. 2006. Environmental leaders: making a difference. A typology of environmental leaders and recommendations for a differentiated policy approach. Business Strategy and the Environment I7(3): 160-I78.

Schaltegger S. 2002. A framework for ecopreneurship: leading bioneers and environmental managers to ecopreneurship. Greener Management International (38): 45-58.

Schumpeter JA. I936. The Theory of Economic Development. Harvard University Press: Cambridge.

Schwartz EB. I979. Entrepreneurship: a new female frontier. Journal of Contemporary Business Winter: 47-76.

Seuring S. 2004. Integrated chain management and supply chain comparitive analysis and illustrative cases. Journal of Cleaner Production I2(8-IO): I059-IO7I.

Silverman M, Marshall RS, et al. 2005. The greening of the California wine industry: implications for regulators and industry associations Journal of Wine Research 16(2): I5I-169.

Socolow RH. I994. Industrial Ecology and Global Change. Cambridge University Press: Cambridge.

Tibbs H. I99. Industrial Ecology: a New Environmental Agenda for Industry. Global Business Network: Emeryville, CA.

Timmons JA, Spinelli S. 2004. New Venture Creation Entrepreneurship for the 21st Century (6th edn). McGraw-Hill: New York; 700.

United States Department of Agriculture. 2008. World Markets and Trade. United States Department of Agriculture. http://www.fas.usda.gov. accessed 5 July 2008.

Van Aardt I, Van Aardt C. 2007. Entrepreneurship and New Venture Management. Oxford University Press: Cape Town, South Africa.

Vermeulen WJV. 2008. Sustainable Global Product Chains: actors, systems and mechanisms at three levels. $14^{\text {th }}$ Annual International Sustainable Development Research Conference, September 2I-23, 2008.

Vermeulen WJ, Ras PJ. 2006. The challenge of greening global product chains: meeting both ends. Sustainable Development I4(4): 245-256.

\section{Appendix. Details of the Factor Analysis on Entrepreneurship Questions}

The result of the analysis in Table 3 is as follows. The Kaiser-Meyer-Olkin measure of sampling adequacy (KMO) value is 0.745 and is more than 0.6. The result of the Barlett test is approx. chi-square 62I.6, $\mathrm{df}=66$, significance $=0.00$, thus significant, as it is smaller than 0.05 . Based on these results the use of a factor analysis is appropriate. To identify how many components (factors) to extract, the Kaiser criterion identifies three components with initial Eigenvalues of more than unity. These three components explain a total of 5 I. $5 \%$ of the variance (Table Ar). This is also confirmed by the screeplot (Figure AI).

\begin{tabular}{|c|c|c|c|c|c|c|c|}
\hline \multirow[t]{2}{*}{ Component } & \multicolumn{3}{|c|}{ Initial Eigenvalues } & \multicolumn{3}{|c|}{ Extraction sums of squared loadings } & \multirow{2}{*}{$\begin{array}{c}\begin{array}{c}\text { Rotation sums } \\
\text { of squared } \\
\text { loadings }\end{array} \\
\text { Total }\end{array}$} \\
\hline & Total & $\%$ of variance & Cum. \% & Total & $\%$ of variance & Cum. \% & \\
\hline 1 & 3.227 & 26.892 & 26.892 & 3.227 & 26.892 & 26.892 & 1.910 \\
\hline 2 & 1.732 & 14.434 & 41.326 & 1.732 & 14.434 & 41.326 & 2.605 \\
\hline 3 & 1.224 & 10.200 & 51.526 & 1.224 & 10.200 & 51.526 & 2.268 \\
\hline 4 & 1.035 & 8.624 & 60.150 & & & & \\
\hline 5 & 0.860 & 7.170 & 67.320 & & & & \\
\hline 6 & 0.807 & 6.728 & 74.047 & & & & \\
\hline 7 & 0.776 & 6.464 & 80.512 & & & & \\
\hline 8 & 0.682 & 5.685 & 86.197 & & & & \\
\hline 9 & 0.547 & 4.560 & 90.757 & & & & \\
\hline 10 & 0.469 & 3.912 & 94.669 & & & & \\
\hline 11 & 0.363 & 3.026 & 97.695 & & & & \\
\hline
\end{tabular}

Table A1. Total variance explained in factor analysis on entrepreneurship questions

Extraction method: principal component analysis.

${ }^{a}$ When components are correlated, sums of squared loadings cannot be added to obtain a total variance. 


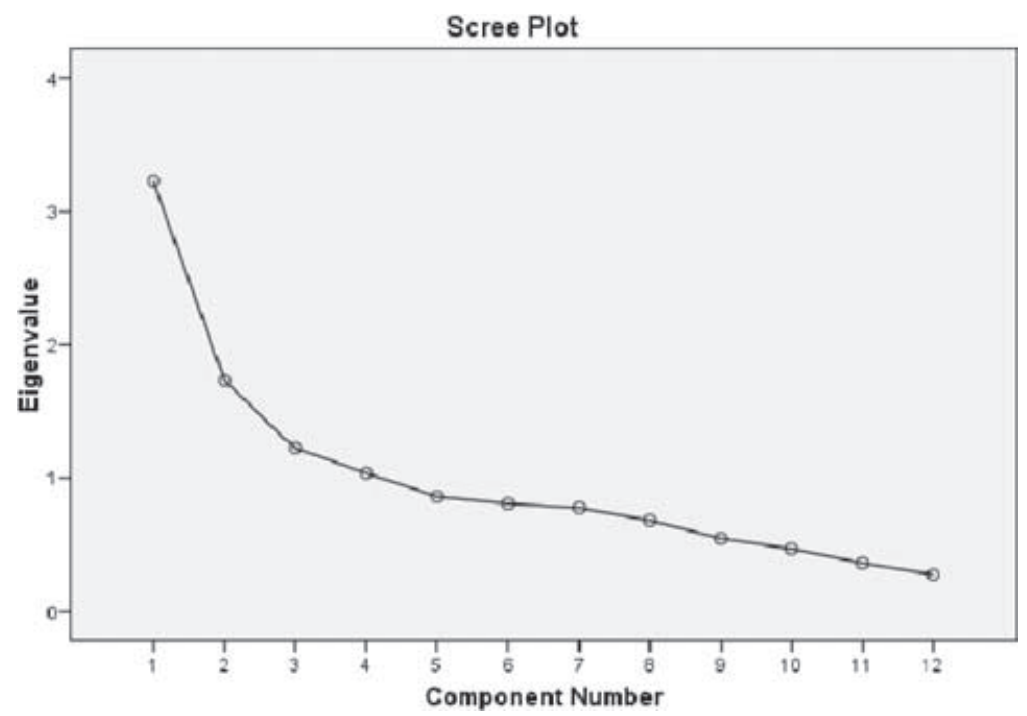

Figure A1. Screeplot of Eigenvalues in factor analysis on entrepreneurship questions

The result was that three constructs were obtained. The use of the histograms was to group the variable values and it is useful as it displays the intervals of distribution, even those without observed values, and examines the shape of the distribution for skewness, kurtosis and the model pattern. The shapes and distributions of the three histograms are all acceptable. 